\title{
A Study on the Effects of Global Warming in Bangladesh
}

\author{
Fahim Elahi, Niazul Islam Khan \\ Department of Electrical and Electronic Engineering (EEE), East West University, Dhaka, Bangladesh \\ Email address: \\ fahimprotik@hotmail.com (F. Elahi),niaz.eee04@gmail.com (N. I. Khan) \\ To cite this article: \\ Fahim Elahi, Niazul Islam Khan. A Study on the Effects of Global Warming in Bangladesh. International Journal of Environmental \\ Monitoring and Analysis. Vol. 3, No. 3, 2015, pp. 118-122. doi: 10.11648/j.ijema.20150303.12
}

\begin{abstract}
Global warming turns out to be the biggest challenge to the mankind in the near future. It is not a problem to write only theories and do research on; it is a problem which humankind must face unless proactive measures are taken immediately. Global warming causes the climate to change including the rise of sea-level. Recently, the IPCC (Intergovernmental Panel on Climate Change), in its Fifth Assessment Report, has suggested a $1.5 \mathrm{~mm}$ sea-level rise per year for Bangladesh. As a developing country, where around half of the total population is below the poverty line, Bangladesh is going to be one of the worst sufferers of this due to its disaster prone and low elevation geography. This paper will explore the impacts of global warming on Bangladesh. Preparation of Bangladesh to face the adverse effects of global warming will also be presented. At the end of the paper, few recommendations for reducing the carbon emission have been suggested.
\end{abstract}

Keyword: Fossil Fuel, Climate Change, Sea-Level Rise, Temperature, Green House Effect

\section{Introduction}

The temperature of the earth has increased significantly over the past few decades. Scientists around the world have predicted that the average temperature of the Earth's atmosphere will increase by $2^{\circ}$ to $6^{\circ}$ Celsius by the end of the 21 st century unless appropriate measures are not taken [1]. The Industrial Revolution has played the principal role in triggering this rise, followed by other human activities like burning of fossil fuels, deforestation, etc. Release of greenhouse gases like carbon dioxide, methane, nitrous oxide and fluorinated gases [2] trap the heat in the atmosphere, leading to global warming. Global warming has resulted in climate change in numerous aspects like rising in sea-levels, frequent severe storms and even the extinction of some major species.

Bangladesh, with its disaster prone geology and low elevation, is one of the top most nations vulnerable to climate change. Though Bangladesh is little responsible for global warming in compared to the developed countries, it is one of worst sufferers of it. IPCC also recognizes Bangladesh as one of the most vulnerable countries in the world to the negative impacts of climate change. Different climate change effects like extreme hot in summer, extreme cold in winter, shifting of the seasons, recurring floods, river bank erosion, drought in dry season, salinity increase as back water effect, lowering ground water level etc. have been contributing to augment the vulnerability of many regions of the country.

\section{Global Warming: A Consequence of Green House Effect}

Global warming refers to the continuos increase of the Earth's climate system. It is going to be one of the biggest environmental and humanitarian crises in the very foreseeable future. A lot of reasons are responsible for global warming. In 2007, the Intergovernmental Panel on Climate Change (IPCC) of the United Nations reported with more than $90 \%$ certainty that man-made generation of $\mathrm{CO}_{2}$ is the primary cause of global warming [3] [4]. In 2013, the IPCC concluded that the largest driver of global warming is carbon dioxide $\left(\mathrm{CO}_{2}\right)$ emissions from fossil fuel combustion, cement production, and land use changes such as deforestation [5].Tropical deforestation is another major contributor to global warming. When these forests are burned, they release huge amounts of carbon into the atmosphere and the forests no longer available to absorb $\mathrm{CO}_{2}[6]$.

\section{Global Warming: Impacts on Bangladesh}

Though Bangladesh contributes lowest (only 0.3\%) to the amount of emission driving global warming, it is one of the 
worst victim of global warming effects. The country tops the Global Climate Risk Index, a ranking of 170 countries most vulnerable to climate change, published in 2009 and compiled by Germanwatch, an international nongovernmental organization that works on environment and development issues [9]. The effects of global warming leads to climate change in various aspects. Though all the climate change aspects are related to each other, they are described below separately.

\section{Rise of Temperature}

Now global warming is not any more a hypothetical issue. It is an issue which can be visualized all around.Due to rapid industrialization, green houses gases (GHGs) such as carbondioxide, methane, nitrous oxides, chlorofluorocarbon (CFC) have been increased significantly over the last century.

Scientists have predicted that the world will experience an average temperature rise of $2^{0} \mathrm{C}$ in the next decades. According to the Bangladesh Meteorological Department (BMD), Bangladesh has experienced an average temperature rise of $0.6^{0} \mathrm{C}$ over the last 100 years and the Dhaka city, the capital has got an increase of $2^{0} \mathrm{C}$ during the same period. According to the research in Bangladesh University of Engineering and Technology (BUET), $65 \%$ of Dhaka city has a temperature $3-5^{\circ} \mathrm{C}$ higher than the average temperature in Dhaka. Some of these areas have seen a temperature rise of $6^{0} \mathrm{C}$ over a period of about 24 years [10]. This year in 2014 (24 April), Dhaka has the highest temperature of $40.2^{\circ} \mathrm{C}$ in the last 54 years. This temperature is about $8^{0} \mathrm{C}$ above the usual maximum temperature in Dhaka in April [11]. The main reasons for this unusual temperature rise in Dhaka are the unplanned urbanization, excessive population density, and the increase of cars, and public transports in the city. Also the use of fridges and air conditioners used by the dense city dwellers make a huge amount of HFCs (hydrofluocarbons) contribution to the air, which destroys the protective ozone layer of the Earth. These gases are more dangerous than $\mathrm{CO}_{2}$ as they have a heat trapping capability of 1600 times larger than $\mathrm{CO}_{2}$ [12].

This year in 2014, the intolerable temperature rise caused many of the city dwellers of Dhaka to install air conditioners in their apartments. Air conditioners require too much electricity, the generation of which by conventional methods will emit more $\mathrm{CO} 2$ in the atmosphere heating up the environment even more [13] [14]. So the city is heating up in cyclic way.

\section{Sea-Level Rise and Inundation of Low-Lying Lands}

Recently, European Research Agency has revealed their research on ice melting in the Antarctica. In those revelations, they have found that the current rate of melting of the ice in the Western Antarctica is two times greater than what was 4 years before. The research finds that the Western Antarctica is loosing 159 billion tonnes of ice per year which may increase the sea-level by $0.5 \mathrm{~mm}$ per year [15]. According to the IPCC Fifth Assessment Report published recently, the sea-level of the Bay of Bengal is rising at a rate of $1.5 \mathrm{~mm}$ per year. Bangladesh with the Bay of Bengal on the South will be directly affected by the sea-level rise because of its low elevation. If the sea-level rises by $45 \mathrm{~cm}$, a permanent loss of up to 15600 square kilometres of land is expected. If one meter rise happens, around 14000-30,000 sq. km land are expected to be flooded, which means more than $20 \%$ of Bangladesh will be under water [16]. Scientists predict that rising sea-levels to submerge 17 percent of Bangladesh's land area will displace 18 million people in the next 40 years by $2050[17]$.

\section{Frequent Storms and Floods}

Scientists believe that rising temperatures will lead to more extreme weather worldwide, including stronger and more frequent cyclones in the Bay of Bengal. And rising seas will make any storm more dangerous because flooding will become more likely to accompany [17]. Bangladesh is particularly at risk because the country, with its low elevation, is crisscrossed by as many as 230 rivers, many of which unstably swell during the monsoon rains [17], [9]. According to data from the government's Centre for Environmental and Geographic Information Systems (CEGIS), two-thirds of the country is only five metres above sea-level. This geology, along with river water from the melting Himalayan glaciers in the north caused by the temperature rise, makes the region more vulnerable to severe flooding. The situation is worsened by the prevalence of intense storms, a marker of climate stresses. Sidr, the Category 4 cyclone that ravaged southern Bangladesh in November 2007, killed some 3,500 people, displaced 2 million, and wiped out paddy fields. Sidr was followed by two heavier-than-normal floods that killed some 1,500 people and damaged about 2 million tons of food.

\section{Salinity of Ground Water}

With the rise of seal level, the saline sea water from the Bay of Bengal intrudes to the farmlands, which jeopardizes the food output in Bangladesh. Particularly, rice production is significantly affected by this saline water. A 2007 report by the IPCC estimates that the production of staple foods could drop steeply by 2050 because of soil salinity. This would be devastating in a country where agriculture is the key economic driver with around $65 \%$ of the total population being employed in agriculture [9]. This sector accounts for about 22 percent of the nation's economic output, with an additional 33 percent derived from the rural non-farm economy, which is also linked to agriculture, according to the World Bank. Moreover, the salinity intrusion is gradually destroying the Sundarbans, the largest mangrove forest in the world. 


\section{Effects on Agriculture and Fisheries}

The three cropping seasons in Bangladesh namely Rabi, Kharif-I, Kharif-II may be negatively affected by the climate change effects. Due to drought and lowering of ground water, irrigation will be obstructed as the largest demand for surface and ground water is to support the irrigation of crops in dry months. Increase in temperature may rise the irrigation demands to $200 \mathrm{Mm}^{3}$ in the month of March alone [18]. Moreover, flooding causes a loss of arable lands causing a drop in the crop yield. The IPCC estimates that Central and South Asia can expect a 30 percent drop in yield by 2050 [19].

Bangladesh is a land of rivers. Being so, fish is a part of their daily meals and many people in the coastal areas have undertaken fishing as their livelihood. Fisheries sector contribute to $3-5 \%$ of the GDP of the country [18]. Global warming will also affect the fisheries of the country. Since the solubility of oxygen in water decreases with increasing temperature, it could be a problem for fisheries. Also the reduced river flowing during the dry season worsens the problem. Besides, freshwater fishes will face a survival problem in the south western part of Bangladesh because of increased salinity from sea-level rise [18].

\section{Health Hazards}

Global warming has significant effects on human health. Mosquito-borne diseases like malaria can be a threat because of warmer weather [21]. Infectious disease like dengue fever caused by dengue virus can be another consequence of warmer weather. According to ICDDR,B (International Centre for Diarrhoeal Disease Research), climate change will make the people of Bangladesh more vulnerable to disease like Cholera, dengue, cardiovascular and respiratory disease, and malnutrition because of reduction of food production[20]. This year in April (2014), there were a serious heat waves in the country that triggered illness, mainly viral infections and gastroenteric disorders [22].

Climate change has also an impact on mental health. According to American Psychologist Clayton \& Doherty, global climate change has substantial negative impacts on mental health and well-being. Main victims are the vulnerable populations and those with pre-existing serious mental illness [21].

Apart from the above stated consequences of global warming Bangladesh may face a lot of climate abnormalities like unpredictable weather pattern, seasonal irregularities, food and water insecurity etc.

\section{Global Warming: How Bangladesh Is Preparing to Face the Challenges}

The preparation of Bangladesh to face the challenges of global warming, though not enough, cannot be overlooked. It has gone a long way to protect its people by developing an early-warning system and building at least 2,500 concrete storm shelters. This has resulted in a vast reduction in storm- related deaths [17].The country has so far invested more than US $\$ 1,50,000$ to reduce vulnerability to natural disasters by building embankments and cyclone shelters and creating a storm early-warning system [20]. But billions more are needed to build similar infrastructure in the next 15 years to mitigate the threats, along with enhancing research on climate-resistant agriculture.

Bangladesh Rice Research Institute (BRRI) is working to devise salt-tolerant strains of food crops, especially rice. Scientists from BRRI are also striving to breed Saltol-a gene on the rice chromosome that confers salinity tolerance at the seedling stage-into different varieties of rice. The institute is also developing water management technology to capture fresh water during the monsoon, when soil salinity is less prevalent. This stored fresh water can be used for irrigating rice during the dry season.

Adaptation initiatives are visible in the community level to fight the growing of crops in the flood prone areas. One example of this adaptation activity is the 'floating bed agriculture,' where crops and vegetables can be grown on floating platforms during inundation of land. Reducing Vulnerability to Climate Change (RVCC) was the first project of its kind on Community Based Adaptation (CBA) to climate change.

The GoB is appealing for more aid from the industrialized countries that are the largest emitters of greenhouse gases and are responsible for global warming, to help Bangladesh adapt and avoid calamity. With the help of the development partners and World Bank, the Government of Bangladesh (GoB) established Bangladesh Climate Change Resilience Fund (BCCRF) in May, 2010. This fund is enabling the GoB to channel in over US\$ 188 million to millions of Bangladeshis to fight the effects of climate change. GoB has another fund called the Bangladesh Climate Change Trust Fund in order to address the climate change effects. It has allocated US\$ 350 million from its own resources for the last five years consecutively from 2009 to 2013 .

The GoB is also trying to introduce clean energy sources instead of conventional sources that are responsible for emitting GHGs. It has already targeted a $5 \%$ of the total electricity generation from renewable sources by 2015 of which $500 \mathrm{MW}$ will be from solar. Along with this, the GoB has undertaken a major project of generating electricity by nuclear energy at Ruppur. This will contribute significantly to the reduction of carbon emission to the atmosphere. In this regard, the following measures are recommended to reduce the carbon emission in the country's atmosphere:

1. Carbon emitting activities should be discouraged. The GoB can do this by increasing the tax for the companies emitting carbons to the atmosphere. This tax should be proportionate to the amount of carbon emitted by that company.

2. Air conditioners (ACs) should not be allowed as an appliance of luxury. For this, residential buildings should not be allowed for installing ACs.

3. Illegal deforestation should be severely deal with. Strict laws should be passed in the parliament with the 
provision of punishment and restitution for illegal cutting of trees. In Dhaka city, trees can be grown on the building tops.

4. Cars driven by renewable energy sources should be introduced.

5. The GoB should reduce duty on the import of all the energy efficient products. For an example, the price of the energy efficient bulbs like LED bulbs, CFL bulbs should be lowered.

6. Alternative power sources like solar power should be introduced extensively instead of conventional power sources. Bangladesh has a $724 \mathrm{~km}$ long coast line and many small islands in the Bay of Bengal, which have potential for wind energy generation .Bangladesh has also potential for harnessing ocean wave energy from the Bay of Bengal.

\section{Conclusion}

This paper has discussed the effects of global warming on Bangladesh and its initiatives to mitigate changes. Bangladesh received the climate change initiative award 'Lighthouse Activities 2013' for its outstanding contribution to climate change adaptation [23].It has shown its urgency to move towards the green sources of energy. About 2,677,896 solar home systems (SHS) s have already been installed by the end of November 2013, which mainly covered rural areas

The GoB has taken different initiatives to face the challenges of the global warming. Becoming a developing country, it cannot manage the required funds for this. The developed countries of the world should come forward to help the poor countries in this respect. Moreover, NGOs, the GoB and the civil society should act together to raise awareness among the mass people about global warming, its mitigation and adaptation techniques.

\section{References}

[1] NASA Earth Observatory website [Online]. Available at: http://earthobservatory.nasa.gov/

[2] U.S. Environmental Protection Agency, "Climate ChangeGreenhouse Gas Emissions," 2011 Inventory of Greenhouse Gas Emissions and Sinks prepared by EPA for the years 1990 through 2009.

[3] A. Gore, The Inconvenient Truth, Directed by Davis Guggenheim, 2006.

[4] EPRI Discussion Paper, "The power to reduce $\mathrm{CO} 2$ emissions-The full portfolio," EPRI Energy Technology Assessment Center, Aug., 2007.

[5] Global Warming [Online]. Available at: http://en.wikipedia.org/wiki/Global_warming

[6] Global Warming [Online]. Available at: http://www.ucsusa.org/global_warming/global_warming_101

[7] Greenhouse [Online]. Available at: http://en.wikipedia.org/wiki/Greenhouse
[8] Greenhouse effect [Online]. Available at: http://en.wikipedia.org/wiki/Greenhouse_effect

[9] How Global Warming Threatens Millions in Bangladesh [Online]. Available at: http://www.usnews.com/news/energy/articles/2009/03/26/how -global-warming-threatens-millions-in-bangladesh

[10] $65 \%$ of Land Area of Dhaka City is hot. [Online]. Available ahttp://www.prothom-alo.com/bangladesh/article/203719/

[11] Hottest Day in 54 Years. [Online]. Available at: http://www.prothom-alo.com/bangladesh/article/201178/

[12] Beware Climate Change Risk from Aircon, Frdige Gases: U. N. [Online]. Available at: http://www.reuters.com/article/2011/11/21/us-climate-gasesidUSTRE7AK0GO20111121

[13] Global Warming Alarmists Seek to Restrict Air Conditioning. [Online]. Available at: http://news.heartland.org/newspaperarticle/2013/07/23/global-warming-alarmists-seek-restrict-airconditioning

[14] Study: Air Conditioning May Indirectly Contribute to Global Warming. [Online]. Available at: http://www.foxnews.com/story/2006/08/02/study-airconditioning-may-indirectly-contribute-to-global-warming/

[15] McMillan, M., A. Sheperd, A. Sundal, K. Briggs, A. Muir, A. Ridout, A. Hogg, et al. "Increased ice losses from Antarctica detected by CryoSat- Geophysical Research Letters, 2014.

[16] S. Butzengeiger, B. Hortsmann, "Sea-level Rise in Bangladesh- One Phenomenon, Many Consequences", Germanwatch, 2004

[17] Borrowed Time on Disappearing Land-Facing Rising Seas, Bangladesh Confronts the Consequences of Climate Change. [Online]. Available at: http://www.nytimes.com/2014/03/29/world/asia/facing-risingseas-bangladesh-confronts-the-consequences-of-climatechange.html?_r=0

[18] A.B.M.S.U. Hasan, M.Z. Rahman, "Change in Temperature over Bangladesh Associated with Degrees of Global warming", Asian Journal of Applied Science and Engineering, Vol. 2 , no. 2, pp. 62-75, 2013

[19] How Bangladesh is preparing for Climate Change. [Online]. Available http://www.scientificamerican.com/article/bangladeshprepares-for-climate

[20] S. A. L. Mahmood, "Impact of Climate Change in Bangladesh: The Role of Public Administration and Government's Integrity", Journal of Ecology and the Natural Environment, Vol. 4, no. 8, pp. 223-240, May 2012.

[21] Effects of global warming on mental health. [Online]. Available at: http://en.wikipedia.org/wiki/Effects_of_global_warming_on_h uman_health

[22] Heat Waves to hang on. [Online]. Available at: http://bdnews24.com/bangladesh/2014/04/20/heatwave-tohang-on

[23] Action Aid Bangladesh wins UNFCCC award. Available at: http://www.newstoday.com.bd/index.php?option=details\&new s_id $=2361134 \&$ date $=2013-11-07$ 